International Journal of Current Advanced Research

ISSN: O: 2319-6475, ISSN: P: 2319 - 6505, Impact Factor: SJIF: 5.995

Available Online at www.journalijcar.org

Volume 6; Issue 5; May 2017; Page No. 3997

DOI: http://dx.doi.org/10.24327/ijcar.2017.3997.0415

CASE REPORT

\title{
THERAPEUTIC MANAGEMENT OF SUSPECTED IPOMOEA CARNEA TOXICITY IN A GOAT
}

\author{
Yadav S.N., Phukan A., Kalita D.N., Barman D., Dutta T.C and Sarma J
}

Department of Veterinary Clinical Medicine, Ethics and Jurisprudence College of Veterinary Science, Assam Agricultural University, Guwahati PIN-781022

\section{A R T I C L E I N F O}

\section{Article History:}

Received $11^{\text {th }}$ February, 2017

Received in revised form $15^{\text {th }}$ March, 2017

Accepted $14^{\text {th }}$ April, 2017

Published online $28^{\text {th }}$ May, 2017

\begin{abstract}
A B S T R A C T
A goat was presented in a local farm near Guwahati, Assam with incoordination, ataxia and staggering gait. Farmer reported goat consumed leaves of Ipomoea plant. Further, based on the clinical symptoms and history the goat was suspected as a case of Ipomoea toxicity. The goat was stabilized with intravenous infusion of $5 \%$ dextrose, Vit-C and nerve tonic injection. The goat recovered 24-25 hour after the therapeutic management.
\end{abstract}

Key words:

Goat; ipomoea toxicity; management

Copyright $₫ 2017$ Yadav S.N et al. This is an open access article distributed under the Creative Commons Attribution License, which permits unrestricted use, distribution, and reproduction in any medium, provided the original work is properly cited.

\section{INTRODUCTION}

Goats which graze on the leaves of Ipomoea Carnea, a toxic plant specially during summer and draught period become prone to its toxic effect (Tirkey et. al., 1987). Important toxicity sign are lethargy, muscle tremor, hyperexcitability, dilated pupils, opisthotonus, strabismus, weakness of the hind limbs, severe incoordination, atxia, wasting and recumbence (Tokarnia et al. 2002). In this clinical case the goat consumed leaves of Ipomoea Carnea (locally known as kolmoh).

\section{Case history and Observation}

A two year old non-descript doe was presented with inappetance accompanied by various neurological signs such as staggering gait, aimless walking and mild ataxic. Clinical inspection of the goat revealed normal temperature, normal pulse rate, normal respiration, staggering gait.

It was suspected to be a case of Ipomoea toxicity.

\section{Treatment and Discussion}

To stabilize the goat treatment was rendered immediately by intravenous infusion of $5 \%$ dextrose @ $10 \mathrm{ml} / \mathrm{kg}$ body weight intravenously, Vit.- C @ 50 mg/animal orally and neurobion forte $2 \mathrm{ml} /$ per animal intramuscullarly. This was in accordance with the review of Vadlamudi (2011). Additionally, Vadlamudi (loc.cit) could not explain the therapeutic basis of this treatment. Neurobion forte was administered as nerve tonic as the animal was exhibiting different neurological signs.

*Corresponding author: Yadav S.N

Department of Veterinary Clinical Medicine, Ethics and Jurisprudence College of Veterinary Science, Assam Agricultural University, Guwahati PIN-781022
No proper literature was present for treatment of Ipomoea toxicity, so an attempt was made to save the life of the animal with very few literature present and providing the symptomatic treatment. Further, the fluid therapy was repeated at 6 hours interval for first day then 12 hours interval for next two days. In the present case, the goat was initially which was ataxic subsequently returned to normalcy after an aggressive intensive therapy.

Ipomoea carnea toxicity requires to be prevented in the inception before the toxicity by providing or implementing proper dietary management procedures in animal as animal consume this plant in absence of proper feeding.

\section{References}

Tirkey, K.; Yadava, K.P.; Jha, G.J. and Banerjee, N.C. (1987). Effect of feeding of Ipomoea carnea leaves on goat. Indian J. Anim. Sci. 57 (88): 863-866

Tokarna, C.H.; Dobereiner, J. and Peixoto, P.V. (2000). Plantas Toxicas do Brasil. Editora Helianthus, Rio de Janerio, p.120-122

Vadlamundi, V.P. (2011) Veterinary Toxicology. Editor Satish K.Garg, New Delhi, p.102-103 